\title{
Sizing Up Integrated Reporting Disclosure and Value: The Indonesia and Singapore Cases
}

\author{
Dwiarso Utomo ${ }^{1, *}$, Zaky Machmuddah ${ }^{2}$, Dian Indriana Hapsari ${ }^{3}$ \\ ${ }^{1,2,3}$ Universitas Dian Nuswantoro, Semarang, Indonesia \\ dwiarso.utomo@dsn.dinus.ac.id \\ ABSTRACT
}

The purpose of this study is to provide empirical evidence regarding the relationship between Integrated Reporting Disclosure (IRD) and corporate value, moderated by company size. The research object is an IDX and SGX-registered manufacturing enterprise. Based on predefined sample parameters, several observational data points relating to these variables were collected. The data were analyzed using WarpPLS version 7.0. The research findings indicate a significant association between corporate worth and IRD, albeit moderated by company size. This research implies that IRD plays a critical role in increasing a company's price and that revealing IRD increases the company's value. This is extremely important for the organization's sustainability, as IRD adds value over time.

Keywords: integrated reporting disclosure, company size, company value.

\section{INTRODUCTION}

The COVID-19 pandemic is still active and affecting a variety of sectors. The COVID-19 pandemic has had a significant economic impact on the health sector. Certain countries, including ASEAN member states, are suffering the economic consequences of the COVID-19 pandemic. However, not all ASEAN members will be affected economically by the COVID-19 pandemic in 2020. Indonesia is one of the ASEAN member countries feeling the pinch, as evidenced by the Purchasing Manager's Index (PMI) falling to 40.1 in July 2020 from 53.5 in June. However, Singapore's economy has increased to 56.3 from 50.0 (https://ekonomi.bisnis.com/). This incident will undoubtedly serve as a barometer of the manufacturing sector's performance. This information will certainly influence prospective investors' and existing investors' investment decisions.

As a result, issuers should provide the best information possible to increase the company's value and influence potential investors and investors. Traditional financial reports appear incapable of capturing the consequences of timely economic change and business innovation [1]. This is consistent with [2], which states that financial statements have become increasingly complex, irrelevant, and messy over the last decade, which concerns investors. Although issuers have also presented non-financial reports such as sustainability reports, integrated financial and non-financial reports that help potential investors and investors understand the business are not yet available from issuers [3]. The emergence of a new paradigm for reporting on economic, social, and environmental activities integrated into a single unit will affect the company's performance and is a manifestation of the company's ethical responsibility in conducting business [4]. The report is referred to as integrated reporting. It serves as a tool for communicating the company's performance, corporate governance, strategy, and prospects in the external environment in the short, medium, and long term [5]. Numerous studies have established that IRD affects a company's value [6], [7], [8], [9], [10], and [11]. However, other researchers demonstrate the opposite, namely that IRD does not affect the company's value [12], [13], [14]. The enterprise sizes can bolster the relationship between IRD and enterprise value. The company's size demonstrates that it is growing and possesses financial strength. This means that the larger the company, the stronger the correlation between IRD and company value. Large companies are more likely to face greater public demand for information than small businesses [15]. This is consistent with research findings from [16] and [17], which indicate that the size of the business has a moderating effect on the amount of intellectual capital disclosed relative to the company's value. However, it contradicts [18], which establishes that the size of the business does not affect the impact of corporate social responsibility disclosure on the company's value. 
The explanations mentioned above and the phenomena serve as a foundation for establishing the research objectives. The purpose of this study is to elucidate the relationship between IRD and company value and the moderating effect of company size on this relationship.

\section{LITERATURE REVIEW HYPOTHESES DEVELOPMENT}

AND

The root of signal theory is pragmatic accounting theory, which focuses on information users who are influenced by information. A company's disclosure is an example of information used to communicate. Later on, it may affect the issuer's security price rise and fall. A business was seeking IRD signals that the quality of existing information is being improved. Environmental and social accounting is frequently used as an alternative to traditional financial reporting by high-quality businesses. On the other hand, lowquality companies maintain consistency by restricting access to accounting information to third parties. Integrated reporting establishes clear connections between corporate strategy, business model, and value creation. The higher the disclosure quality, the lower the integrated reporting's investor information processing costs. The condition should accelerate the inclusion of company-specific information in asset prices [1], [19], and [20]. Signals are pieces of information that stakeholders receive from informants. IRD illustrates a signal sent by a business to its stakeholders. If the company provides reliable information, the market will respond positively, as evidenced by increased stock prices. On the other hand, if the information is of poor quality, the market will remain immobile. This means that if a company discloses comprehensive, integrated reporting, the company's value will increase; conversely, if the company discloses minimal integrated reporting, the company's value will decrease. It is supported by research findings [6], [7], [8], [9], [10], [11], which demonstrate a positive correlation between company value and IRD. The first hypothesis is as follows: H1. IRD increases the value of a business. The size of a company is directly related to its size. The larger the company, the greater the public demand for information [15]. This is consistent with signal theory's concept of the information's transmission quality. Thus, the relationship between IRD and company value will be strengthened due to the firm's size. This means that the more the company's IRD can be maintained, the higher the company's value can be increased. This is consistent with research findings from [16], [17], which indicate that company size has a moderating effect on the impact of intellectual capital disclosure on company value. H2. The size of the enterprise moderates the relationship between IRD and enterprise value.

\section{RESEARCH METHOD}

Quantitative research is being conducted in this study. It makes use of secondary data from IDX and SGX. The study population is comprised of manufacturing companies listed on IDX and SGX, but the research sample was determined according to predefined criteria. These criteria include, but are not limited to, the basic chemical industry, the consumer goods industry, and various industries. Businesses must provide integrated reporting and have complete data for research variables. Data were collected between 2016 and 2020, totaling 300 observations. Tobin's Q [21] is used to approximate the company value variable.

Tobin's $\mathbf{Q}=(\mathrm{MVS}+\mathrm{D}) / \mathrm{TA}$

MVS = value of market of all outstanding shares, i.e. the share price of company* extraordinary shares

TA = Assets of company, such as; cash, accounts receivable, inventory and land book value

$\mathbf{D}=$ debt

Index Integrated reporting is used to quantify IRD, with the total items disclosed divided by the total required to be disclosed ( 8 items) [6]. While the natural logarithm of total assets is used to calculate the company's size [22], [23]. The data analysis tool used was Partial Least Squares (PLS) - Structural Equation Modeling (SEM) 7.0.

\section{RESULTS AND DISCUSSION}

\subsection{Integrated Reporting Disclosure and Stock Price}

The research findings corroborated the development of the hypothesis. As illustrated in Figure 1, the relationship between IRD and company value has a $P$ value of 0.02 , indicating that IRD is related to company value. The more information an issuer submits to the IRD, the higher the company's value. In other words, the information presented in the IRD improves the quality of information available to issuers, affecting the investment decisions made by potential investors or investors, thereby increasing the company's value. This is consistent with signal theory, which states that positive news will trigger a market reaction. This evidence is backed up by research [6], [7], [8], [9], [10], and [11], which all find a positive correlation between company value and IRD. By contrast, this evidence contradicts[12],[13], and[14], which assert that company value is unrelated to IRD. 


\subsection{Company Size Influences Integrated Reporting Disclosures and Value}

According to Figure 1, the $\mathrm{P}$ value for the role of company size in moderating the relationship between IRD and company value is 0.04 . This means that the relationship between IRD and enterprise value is facilitated by the size of the enterprise. This is because as a company's size increases, the public demand for information increases, and as a result, large companies provide more information to the public. Thus, as a company's size increases, the relationship between IRD and company value strengthens. The above explanation is consistent with signal theory, which explains how public information is transmitted. The obtained results is consistent with [16], [17], which demonstrate that intellectual capital disclosure is associated with increased company value, which is moderated by the size of the company. This is in contrast to [18], which demonstrates that the effect of corporate social responsibility disclosure on company value is unaffected by the size of the company.

Table 1. Goodnes of Fit Structural Model

\begin{tabular}{lcc}
\hline & Criteria & Parameter \\
\hline APC & $0.109, \mathrm{P}<0.014$ \\
AVIF & 1.031 \\
AFVIF & 1.045 \\
GoF & 0.167 \\
RSCR & 1.000 \\
SSR & 1.000 \\
\hline
\end{tabular}

Source: secondary data processed, 2021

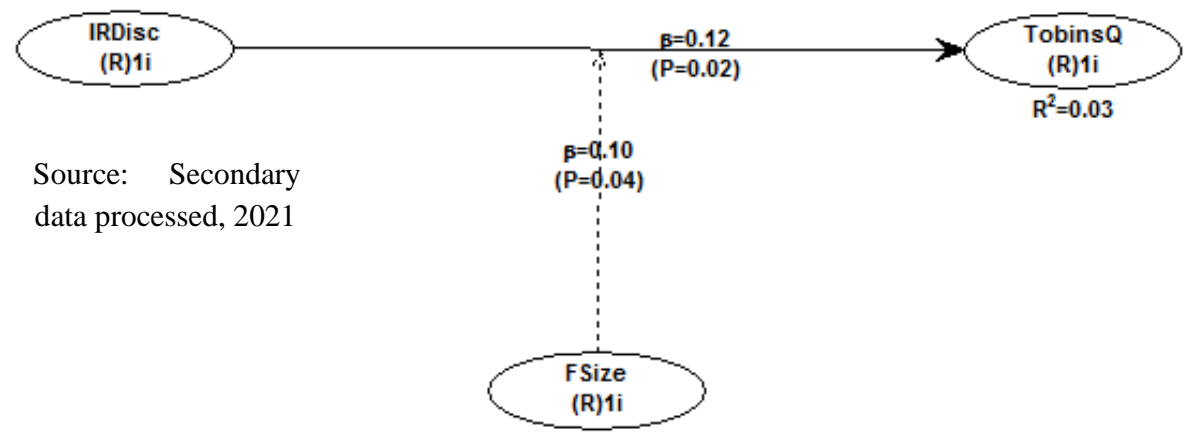

Fig. 1. Research result

\section{CONCLUSION AND RECOMMENDATION}

This study established that firm value is related to IRD and that firm size strengthens the relationship between IRD and firm value. This means that the more IRD a business conducts, the more valuable the business becomes. Additionally, the relationship between IRD and company value is more substantial as the company's size increases. The study's findings imply the importance of IRD for many businesses to increase company value. The low $\mathrm{R}$ square value in the WarpPLS test results, which is only $3 \%$, is used as a limitation of this study because it cannot be generalized to other companies; consequently, the recommendations for further research include the addition of independent variables and modification of the research model to obtain findings. This research contributes by providing an overview of the importance of IRD to regulators and issuers.

\section{REFERENCES}

[1] Healy, P. M. and Palepu, K. G. Information asimmetry, corporate disclosure, and the capital markets : a review of the empirical 
disclosure literature. J account econ, 31(1-3), 405-440 (2001).

[2] Financial reporting council (FRC) cutting clutter. Combating clutter in annual reports, (2011).

[3] KPMG and financial executives research foundation. Disclosure overload and complexity: hidden in plan sight, (2011).

[4] Lodhia, S. Exploring the transition to integrated reporting through a practice lens: an Australian customer owned bank perspective. Journal business ethics, 129, 585-598 (2015).

[5] International integrated reporting coucil (IIRS). International integrated reporting framework, (2013).

[6] Lee, K. W., and G. H. H. Yeo. The association between integrated reporting and firm valuation. Review of quantitative finance and accounting, 47(4), 1221-1250 (2016).

[7] Mervelskemper, L. and Streit, D. Enhancing market valuation of ESG performance: is integrated reporting keeping its promise?. Business strategy and the environment, 26(4), 536-549 (2016).

[8] Martinez, C. Effects of integrated reporting on the firm's value: evidence from voluntary adopters of the IIRC's framework. SSRN Electronic Journal, vailable at SSRN: https://ssrn.com/abstract $=2876145$ or http://dx.doi.org/10.2139/ssrn.2876145 (2016).

[9] Barth, M. E., Cahan, S. F., Chen, L., Venter, E. R. The economic consequences associated with integrated reporting quality: capital market and real effects. Accounting, organizations and society, Working paper 3546, 1-52 (2017).

[10] Cosma, S., M. G. Soana, and A. Venturelli. Does the market reward integrated report quality?. African journal of business management, 12(4), 78-91 (2018).

[11]El Deeb, M. S. The impact of integrated reporting on firm value and performance: evidence from Egypt. Alexandria journal of accountin research, 3(2), 1-50 (2019).

[12]Churet, C., R. SAM, and R. G. Eccles. Integrated reporting, quality of management, and financial performance. Journal of applied corporate finance, 26(1), 816 (2014)

[13] Suttipun, M. The effect of integrated reporting on corporate financial performance: evidence from Thailand. Corporate ownership and control, 15(1), 133142 (2017).

[14] Nurkumalasari, I. S., Restuningdiah, N., \& Sidharta, E. A. Integrated reporting disclosure and its impact on firm value: Evidence in Asia. International Journal of Business, Economics and Law, 18(5), 99-108 (2019).

[15] Indraswari, G. and Astika, I. Pengaruh profitabilitas, ukuran perusahaan dan kepemilikan saham publik terhadap pengungkapan csr. E jurnal akuntansi, 9(3), 816-828 (2014).

[16] Ardiantini, N. P. N., Surasni, N. K., Sukma, A. A. Financial performance and intellectual capital disclosure as determinants of the value of banking companies with company size as moderating. International journal of social science and business, 4(3), 414-421 (2020).

[17] Purwati, L. Pengaruh intellectual capital terhadap kinerja dan nilai perusahaan dengan ukuran perusahaan sebagai variabel moderasi (studi empiris pada perusahaan manufaktur yang terdaftar di bursa efek indonesia tahun 2012-2016. http://hdl.handle.net/123456789/7677 (2018).

[18]Pohan, H. T., Noor, I. N., Bhakti, Y. F. Pengaruh profitabilitas dan pengungkapan corporate social responsibility terhadap nilai perusahaan, dengan ukuran perusahaan sebagai variabel moderasi. Jurnal akuntansi trisaksi, 5(1), 41-52 (2018).

[19]Sims, C. A. Rational inattention: beyond the linier-quadratic case. Em econ rev, 96(2), 158-163 (2006).

[20] Veldkamp, L. Information market and the co-movement of asset prices. Rev econ stud, 70(3), 823-845 (2006).

[21]Lindenberg, E. B., dan S. A. Ross. Tobin's q ratio and indus-trial organization. Journal of business, 54(1), 1-32 (1981).

[22]Basuroy, S., K. C. Gleason, dan Y. H. Kannan. CEO compensation, customer satisfaction, and firm value. Review of Accounting and Finance, 13 (4), 326-352 (2014).

[23]Feng, M., X. A. Wang, dan J. S. Saini. Monetary compensation, workforceoriented corporate social responsibility, and firm performance. American Journal of Business, 30 (3), 196 215 (2015). 